\title{
COMPARISON OF KARANJIN WITH OTHER NITRIFICATION INHIBITORS FOR RETARDATION OF NITRIFICATION OF UREA N IN SOIL
}

\author{
by K. L. SAHRAWAT*
}

Division of Agricultural Chemicals, Indian Agricultural Research Institute; New Dehli 110012, India

\author{
Key words
}

A.M. Dicyandiamide Inhibition Karanjin Nitrapyrin Nitrification Sandy clay loam

\section{Summary}

Comparative evaluation of Karanjin and three patented nitrification inhibitors for retardation of nitrification of urea in a sandy clay loam showed that the effectiveness of the compounds tested decreased in the order: Nitrapyrin > Karanjin > A.M. > dicyandiamide.

\section{Introduction}

Use of nitrification inhibitors hold promise for improving the efficiency of fertilizer nitrogen under situations where losses due to leaching and denitrification following nitrification are serious. These chemicals retard nitrification in soil thereby reduce the losses due to leaching and denitrification. The large body of literature on the use of nitrification inhibitors that has accumulated is the testimony to their growing importance in improving the efficiency of fertilizer nitrogen for crop production ${ }^{2,3,4,7,9}$.

In an earlier communication we reported Karanjin, the major crystalline principle of karanja (Pongamia glabra Vent.) seed to be a promising inhibitor of nitrification in soil. Karanjin, a furano flavonoid compared well with Nitrapyrin (N-serve) in laboratory incubation tests and greenhouse pot studies with rice crop ${ }^{10,11}$. In the present study the ability of Karanjin to retard nitrification of urea $\mathrm{N}$ has been compared with those of other patented nitrification inhibitors like Nitrapyrin, A.M. and dicyandiamide.

\section{Materials and methods}

The soil used in the study was a surface $(0-15 \mathrm{~cm})$ sample of a sandy clay loam, alluvial soil collected from the farm of the Indian Agricultural Research Institute, New Delhi. The soil was air dried and

\footnotetext{
* Present address: International Crops Research Institute for the Semi-Arid Tropics (ICRISAT), ICRISAT Patancheru P.O., Andhrapradesh 502324 India.
} 
Table 1. Analysis of soil

\begin{tabular}{|c|c|c|c|c|c|c|c|c|}
\hline $\mathrm{pH}^{*}$ & $\begin{array}{c}\text { Organic C } \\
(\%)\end{array}$ & $\begin{array}{c}\text { Total N } \\
(\%)\end{array}$ & $\begin{array}{l}\mathrm{NH}^{+}{ }_{4}-\mathrm{N} \\
(\mu \mathrm{g} / \mathrm{g} \text { soil })\end{array}$ & $\begin{array}{l}\mathrm{NO}_{3}-\mathrm{N} \\
(\mu \mathrm{g} / \mathrm{g} \text { soil })\end{array}$ & $\begin{array}{c}\text { CEC } \\
(\mathrm{meq} / 100 \mathrm{~g})\end{array}$ & $\begin{array}{l}\text { Sand } \\
(\%)\end{array}$ & $\begin{array}{l}\text { Clay } \\
(\%)\end{array}$ & $\begin{array}{c}\mathrm{WHC}^{* *} \\
(\%)\end{array}$ \\
\hline 7.8 & 0.58 & 0.072 & 3 & 7 & 12.3 & 61 & 24 & 42 \\
\hline
\end{tabular}

* 1:2.5 (Soil to water).

** Water holding capacity.

sieved through a 2-mm screen before use. Some important physiochemical properties of the soil are given in Table 1. Soil analyses was done as described earlier ${ }^{6}$.

The nitrification inhibitors tested were: Karanjin (3-methoxy furano-2, 3, 7, 8-flavone) obtained from the Karanja seed ${ }^{11}$, Nitrapyrin 2-chloro-6-(trichloromethyl) pyridine, a patented product of Dow Chemical Co., Midland, Mich; USA; A.M. (2-amino-4-chloro 6-methyl pyrimidine), a nitrification inhibitor obtained from Toyo Koatsu Industries Inc. Tokyo, Japan and dicyandiamide (DCD).

All the compounds tested were added at the rate of the $5 \%$ concentration of urea $\mathrm{N}$ applied. Because of low solubility of Karanjin and Nitrapyrin in water these were dissolved in acetone $(1 \mathrm{ml})$ and applied. The other compounds tested: A.M. and DCD were applied in aqueous solution. Equal amounts of acetone was added to control samples to equalise effect of acetone if any on nitrification.

\section{Incubation procedure}

The following incubation method was used for studing nitrification of urea as affected by different compounds. Ten g of soil sample were held in $125 \mathrm{ml}$ conical flasks and treated with $1 \mathrm{ml}$ of water/or 1 $\mathrm{ml}$ of water containing $1000 \mu \mathrm{g}$ of urea $\mathrm{N}$, and $50 \mu \mathrm{g}$ (or $5 \%$ of urea $\mathrm{N}$ ) of the nitrification inhibitors. The moisture content of the soil was brought to $50 \%$ water holding capacity (WHC) and the samples were incubated at $30^{\circ} \mathrm{C}$. There were thus treatment of urea with and without the nitrification inhibitors along with appropriate controls. The soil samples in duplicate were analysed every other week for $\mathrm{NH}^{+}{ }_{4}, \mathrm{NO}^{-}{ }_{3}, \mathrm{NO}^{-}{ }_{2}\left(\mathrm{ref}^{12}\right)$ and nitrification rates and inhibition of nitrification of urea $\mathrm{N}$ by different compounds were calculated as suggested by Sahrawat ${ }^{8}$. All the results are expressed on oven-dry soil weight basis.

\section{Results and discussion}

Nitrification of urea $\mathrm{N}$ was rapid and 90 per cent of applied urea was nitrified by 7 weeks. Addition of Nitrapyrin, Karanjin, A.M. and DCD retarded nitrification to varying degrees (Table 2). The maximum concentration of $\mathrm{NO}^{-}{ }_{2}$ in all the treatments never exceeded $2 \mathrm{ppm}$ and so have not been reported. Nitrapyn appaered to be the most potent nitrification inhibitor followed by Karanjin, A.M. and DCD. DCD was least effective among the four compounds tested. Nitrapyrin has been the most tested nitrification inhibitor and has proved quite effective (for examples see review by Prasad et al. ${ }^{4}$; Sahrawat ${ }^{8}$ ). DCD has been reported to be a nitrification inhibitor by many workers ${ }^{1,5}$.

Bundy and Bremner ${ }^{1}$ tested the effectiveness of 24 compounds proposed as nitrification inhibitors and found Nitrapyrin to be the most effective. But A.M. and DCD were reported to be quite less effective than Nitrapyrin. Reddy and Datta ${ }^{5}$ studied the retardation of nitrification of different forms of $\mathrm{N}$ fertilizers by DCD and reported that DCD was 
Table 2. Effect of nitrification inhibitors on nitrification of urea $\mathrm{N}^{*}$

\begin{tabular}{|c|c|c|c|c|c|c|c|c|c|c|c|c|}
\hline \multirow[t]{2}{*}{ Treatment } & \multicolumn{3}{|c|}{1 week } & \multicolumn{3}{|c|}{3 week } & \multicolumn{3}{|c|}{5 week } & \multicolumn{3}{|c|}{7 week } \\
\hline & $\mathrm{NH}^{+}$ & $\mathrm{NO}^{-}$ & N.R $R^{* *}$ & $\mathrm{NH}^{+}{ }_{4}$ & $\mathrm{NO}^{-}$ & ${ }_{3}$ N.R & $\mathrm{NH}^{+}$ & $\mathrm{NO}^{-}$ & ${ }_{3}$ N.R & $\mathrm{NH}^{+}$ & $\mathrm{NO}^{-}$ & ${ }_{3}$ N.R \\
\hline Urea alone & 51 & 30 & 37 & 20 & 65 & 76 & 15 & 73 & 83 & 99 & 82 & 90 \\
\hline Urea + Nitrapyrin & 72 & 8 & 10 & 68 & 15 & 18 & 56 & 28 & 33 & 39 & 54 & 58 \\
\hline Urea + Karanjin & 68 & 12 & 15 & 60 & 24 & 28 & 51 & 36 & 41 & 32 & 61 & 66 \\
\hline Urea + A.M. & 65 & 16 & 20 & 55 & 30 & 35 & 46 & 41 & 47 & 23 & 70 & 75 \\
\hline Urea + DCD & 61 & 20 & 25 & 51 & 35 & 41 & 38 & 50 & 57 & 20 & 75 & 79 \\
\hline
\end{tabular}

* Urea was applied at the rate of $100 \mathrm{ppm} \mathrm{N}$ and the inhibitors were added at the rate of $5 \%$ of urea $\mathrm{N}$ (or $5 \mathrm{ppm}$ of soil). The values of $\mathrm{NH}_{4}{ }^{+}$and $\mathrm{NO}_{3}{ }^{-}$presented are the net amounts from urea and the amounts of mineral $\mathrm{N}$ in control (no urea applied) have been subtracted at each sampling.

** N.R.: Nitrification rate, $\%=\frac{\left(\mathrm{NO}^{-}{ }_{3}-\mathrm{N}\right.}{\left(\mathrm{NH}_{4}^{+}+\mathrm{NO}^{-}{ }_{3}\right)-\mathrm{N}} \times 100$.

less effective with ammonium sulfate than with urea $\mathrm{N}$. The maximum precent inhibition of nitrification in a sandy loam by DCD calculated from their data appears to be only $50 \%$ when this compound was added at 5 and $10 \mathrm{ppm}$ concentration to urea during 10 weeks of study. In this study, maximum inhibition of nitrification by the compounds tested were: Nitrapyrin, $76 \%$; Karanjin, $63 \%$; A.M., $54 \%$ and DCD $46 \%$ (Table 3 ).

The results of this study again bring out the effectiveness of karanjin nitrification inhibitor and corroborate our earlier findings where karanjin was compared with Nitrapyrin and was reported to give matching performance with Nitrapyrin ${ }^{11}$. The effectiveness of the compounds proposed as nitrification inhibitors decreased in the order: Nitrapyrin $>$ karanjin $>$ A.M. nitrification inhibitor $>$ DCD. The nitrification rates of urea with Nitrapyrin, Karanjin, A.M. and DCD treated soil after 7 weeks were respectively $58,66,75$ and 79 per cent as compared to 90 per cent nitrification rate obtained in urea without inhibitor treatment (Table 2).

Table 3. Inhibition of nitrification by different compounds

\begin{tabular}{lcccc}
\hline $\begin{array}{l}\text { Nitrification } \\
\text { inhibitor }\end{array}$ & \multicolumn{2}{c}{$\%$ inhibition of nitrification after weeks* } & 7 \\
\cline { 2 - 4 } & 1 & 3 & 5 & 36 \\
\hline Nitrapyrin & 73 & 76 & 60 & 27 \\
Karanjin & 60 & 63 & 51 & 17 \\
A.M. & 46 & 54 & 43 & 12 \\
DCD & 32 & 46 & 31 & \\
\hline
\end{tabular}

* $\%$ Inhibition of nitrification ${ }^{8}$

$=\frac{\text { (Nitrification rate of urea alone) }- \text { (Nitrification rate of inhibitor-treated urea) }}{\text { (Nitrification rate of urea alone) }}$ 


\section{Acknowledgement}

This work was financed by a senior research fellowship from the Indian Council of Agricultural Research, New Dehli. I am thankful to Dr.S. K. Mukerjee, Head, Division of Agricultural Chemicals, Indian Agricultural Research Institute, New Delhi for valuable suggestions, encouragement and facilities provided during these investigations.

Received 27 August 1980.

\section{References}

1 Bundy, L. G. and Bremner, J. M. 1973 Soil Sci. Soc. Am. Proc. 37, 396-398.

2 Huber, D. M. et al. 1977 Bio Science 27, 523-529.

3 Parr, J. F. 1973 J. Environ. Qual. 2, 75-84.

4 Prasad, R. et al. 1971 Adv. Agron. 23, 337-383.

5 Reddy, G. R. and Datta, N. P. 1965 J. Indian Soc. Soil Sci. 13, 135-139.

6 Sahrawat, K. L. 1977 Soil Biol. Biochem. 9, 173-175.

7 Sahrawat, K. L. 1978 In Plant Nutrition 1978. Proc. 8th Intern. Colloquium on Plant Analysis and Fertilizer Problems. pp 431-428. Auckland, New Zealand.

8 Sahrawat, K. L. 1980 Plant and Soil 55, 487-490.

9 Sahrawat, K. L. 1980 Plant and Soil 57, 335-352.

10 Sahrawat, K. L. and Mukerjee, S. K. 1976 Commun. Soil Sci. Plant Anal. 7, 601-607.

11 Sahrawat, K. L. and Mukerjee, S. K. 1977 Plant and Soil 47, 27-36.

12 Sahrawat, K. L. and Prasad, R. 1975 Plant and Soil 42, 305-308. 